\title{
Kebijakan Proteksi Anak Jalanan di Kota Yogyakarta Menurut Perspektif Maqasid Syariah
}

\author{
Khoirul Ummatin* \\ Universitas Islam Negeri (UIN) Sunan Kalijaga Yogyakarta \\ Email: atinumma@gmail.com
}

\begin{abstract}
The problem of street children is a social problem that often occurs in urban areas. We may often meet many children who are on the streets. Such a scene is influenced by a number of factors that cause children to suffer in life on the streets, such as family financial difficulties or pressure from poverty, parental disharmony, and special problems regarding the relationship between children and parents. The existence of street children is often a problem for various parties both from family, community and government. In overcoming the problem, the Yogyakarta city government contributed to provide a solution by issuing regional regulations related to the handling of street children, the regulation considers many aspects such as replacing repressive approaches or forced withdrawal then becoming a humane (persuasive) approach to achieving mutual prosperity. By referring to these objectives, it is appropriate to implement a policy that needs to be based on the concept of maqasid sharia which is a study of Islamic law in establishing a law that must be accompanied by goals which are shar'i (human benefit).
\end{abstract}

Keywords: street children, protection policy, maqasid sharia.

\begin{abstract}
Abstrak
Masalah anak jalanan merupakan sebuah salah satu masalah sosial yang sering terjadi di perkotaan. Kita mungkin sering menemui banyak anakanak yang berada di jalanan,. Pemandangan seperti itu dipengaruhi
\end{abstract}

* Pascasarjana Islam, Pembangunan dan Kebijakan Publik Universitas Islam Negeri (UIN) Sunan Kalijaga Yogyakarta. 
beberapa faktor yang menyebabkan anak-anak terjeremus dalam kehidupan di jalanan, seperti kesulitan keuangan keluarga atau tekanan kemiskinan, ketidakharmonisan rumah tangga orang tua, dan masalah khusus menyangkut hubungan anak dengan orangtua. Keberadaan anak jalanan sering kali menjadi permasalahan berbagai pihak baik dari keluarga, masyarakat maupun pemerintah. Dalam mengatasi masalah tersebut pihak pemerintah Kota Yogyakarta ikut andil memberi solusi dengan mengeluarkan peraturan daerah terkait penanganan anak jalanan, peraturan tersebut mempertimbangkan banyak aspek seperti mengganti pedekatan yang bersifat represif atau penarikan paksa kemudian menjadi pendekatan yang manusiawi (persuasif) sehingga mencapai kesejahteraan bersama. Dengan merujuk pada tujuan terebut, selayaknya mengimplementasikan sebuah kebijakan perlunya didasari dengan konsep maqasid syariah yang merupakan sebuah kajian hukum islam dalam menetapkan sebuah hukum harus disertai tujuan-tujuan yang syar'i (kemaslahatan manusia).

Kata kunci: anak jalanan, kebijakan proteksi, maqasid syariah.

\section{Pendahuluan}

erlindungan anak tidak luput dari perhatian pemerintah
di Indonesia sebagai salah satu agenda tujuan
pembangunan. Seperti telah deklasikan pada tanggal 20 November 1959 Sidang Umum Perserikatan Bangsa-Bangsa telah mengesahkan Hak-Hak Anak. Di dalam deklarasi tersebut secara garis memuat 10 asas tentang hak-hak anak seperti semua anak memiliki hak dan kesempatan yang sama untuk berkembang sehat dan wajar, mendapatkan jaminan sosial, memperoleh perlindungan terhadap segala bentuk yang menyia-yiakan anak, seperti penindasan dan perbuatan yang mengarah kepada diskriminasi. Hal tersebut menyiratkan bahwa pentingnya semua pihak memiliki kewajiban memberikan yang terbaik bagi anak. ${ }^{1}$

${ }^{1}$ Irma Setyowati Soemitro, Aspek Hukum Perlindungan Anak (Jakarta: Bumi Aksara, 1990), 22. 
Anak seharusnya dilindungi, untuk tumbuh kembang anak yang utama berada pada lingkungan keluarga. Karena keluarga lah anak mendapatkan perlindungan, pemeliharaan dan kesejahteraan. Namun pada kenyataannya masih banyak anak-anak yang tidak mendapatkan hak perlindungan, seperti halnya kasus tindak kekerasaan dan penelantaran. Hal tersebut terjadi akibat keluarga tidak mampu lagi melakukan fungsinya dan kurang efektifnya komunikasi yang terjadi antara anak dan orang tua serta lingkungan sosialnya yang menyebabkan anak mencari lingkungannya sendiri yang sesuai dengan dirinya seperti di jalanan. ${ }^{2}$

Masalah anak jalanan merupakan sebuah salah satu masalah sosial yang sering terjadi di perkotaan. Kita mungkin sering menemui banyak anak-anak yang berada di jalanan, seperti di pertigaan jalan atau diperempatan jalan, berada di pinggiran jembatan jalan, atau bahkan di terminal dan lain-lain. Dari beberapa faktor-faktor yang menyebabkan maraknya anak jalanan yaitu kondisi ekonomi yang sering kali memaksa anakanak mengambil inisiatif mencari nafkah atau hidup mandiri di jalanan. Kadang pula pengaruh teman atau kerabat juga ikut menentukan keputusan untuk hidup di jalanan. ${ }^{3}$

Apabila menggambarkan kondisi kehidupan anak jalanan tidak terlepas dari marginal, rentan, eksploitatif. Marginal karena mereka melakukan pekerjaan yang tidak jelas, kurang dihargai dan tidak menjanjikan prospek di masa depan, memiliki resiko yang harus ditanggung akibat jam kerja yang panjang yang berdampak pada kesehatan dan sosial, karena jalanan merupakan tempat yang rawan. Tidak hanya itu anak jalanan juga rawan ekploitatif yang dilakukan oleh preman dan oknum aparat yang tidak bertanggung jawab. ${ }^{4}$

2 Edi Suharto, Pekerjaan Sosial di Indonesia Sejarah Dinamika dan Perkembangan (Yogyakarta: Samudra Biru, 2011), 190.

3Bagong Suyanto, Masalah Sosial Anak, (Jakarta: Kencana, 2010), 210-211.

${ }^{4}$ Bagong Suyanto, Masalah Sosial Anak, 200. 
4 Khoirul Ummatin

Keberadaan anak jalanan sendiri dalam pandangan masyarakat dianggap negatif, karena stigma masyarakat yang menganggap anak jalanan memiliki perilaku yang menyimpang dengan bersikap yang kasar, arogan, dan penganggu ketertiban di jalan.Melihat realitas yang terjadi pada anak jalanan, maka harus adanya tindak untuk mengatasi masalah tersebut oleh semua lapisan masyarakat. Terlebih dari itu pihak pemerintahyang ikut andil dalam mengatasi masalah anak jalanan untuk mendapatkan hak-hak mereka sebagaimana anak pada umumnya yang bersekolah.

Kota Yogyakarta yang merupakan kota pelajar dan budaya pun tidak luput dari keberadaan anak jalanan. Pemerintah Kota Yogyakarta sendiri sudah melakukan berbagai macam cara untuk menangani masalah anak jalanan. Salah satunya adalah mengeluarkan Peraturan Daerah No. 6 tahun 2011 tentang perlindungan anak yang hidup di jalan yang sebelumnya pemerintah membuat rancangan peraturan penanganan anak jalanan dan gepeng menjadi satu, akan tetapi banyak pihak yang tidak setuju terkait hal karena peraturan mengenai gepeng dan anak jalanan merupakan seseuatu yang berbeda, dimana perda anak jalanan lebih menekankan pada aspek perlindungan dan pemenuhan hak-hak anak.

Dengan adanya kebijakan peraturan daerah tersebut pemerintah berusaha melindungi anak jalanan, dimana keberadaan atau posisi anak jalanan tidak dipandang sebagai pelaku kriminal, melainkan sebagai subyek hak yang harus dilindungi dan dipenuhi hak-haknya. Serta Perda tersebut merupakan terobosan baru yang dilakukan pemerintah Kota Yogyakarta dari yang sebelumnya bersifat represif atau penarikan paksa kemudian menjadi pendekatan yang manusiawi (persuasif) kepada anak-anak jalanan.

\section{Pembahasan}


Pengertian anak jalanan menurut Departemen Sosial merupakan anak yang menghabiskan sebagian besar waktunya di jalanan untuk mencari nafkah dan berkeliaran di jalan dan tempat umum. Definisi ini dapat dipahami bahwa anak jalanan adalah anak yang hidup di jalan, dimana mereka bekerja atau bermain-main di jalanan sehingga merampas hak yang sesungguhnya mereka dapatkan. ${ }^{5}$

Adapun pengertian anak jalanan menurut Peraturan Daerah No. 6 tahun 2011 adalah anak yang berusia di bawah 18 (delapan belas) tahun yang menghabiskan sebagaian waktunya di jalan dan tempat-tempat umum yang meliputi anak yang retan bekerja di jalanan, anak yang bekerja di jalanan, dan/atau anak yang bekerja dan hidup di jalanan yang menghabiskan sebagian besar waktunya untuk melakukan kegiataan hidup sehari-hari. ${ }^{6}$

Dengan memiliki kriteria sebagai berikut: ${ }^{7}$

1. Anak yang rentan bekerja di jalanan karena suatu sebab.

2. Anak yang melakukan aktivitas di jalanan

3. Anak yang bekerja atau dipekerjakan di jalanan

4. Jangka waktu di jalanan lebih dari 6 jam per hari dan di hitung untuk 1 bulan yang lalu.

5. Masyarakat dan penguatan lembaga sosial di masyarakat.

Faktor penyebab munculnya anak jalanan sendiri memiliki banyak faktor yang membuat mereka terjerumus dalam kehidupan di jalanan, seperti kesulitan keuangan keluarga atau tekanan kemiskinan, ketidakharmonisan rumah tangga orang tua, dan masalah khusus yang menyangkut hubungan anak dengan orang tua. Hal tersebut yang memaksa

${ }^{5}$ Muhsin Kalida dan Bambang Sukamto, Jejak Kaki Kecil di Jalanan, (Yogyakarta: Cakruk Publishing, 2012), 3.

${ }^{6}$ Peraturan Daerah Provinsi Daerah Istimewa Yogyakarta Nomor 6 Tahun 2011 tentang Perlindungan Anak yang Hidup di Jalan Pasal 1 Ayat 4, 3.

${ }^{7}$ Prosedur Penanganan Anak Jalanan di Kota Yogyakarta yang dibuat oleh Dinas Sosial, Tenaga Kerja, dan Transmigrasi. 
6 Khoirul Ummatin

anak-anak untuk mengambil inisiatif mencari nafkah atau hidup mandiri di jalanan. Kadang pula pengaruh teman atau kerabat juga ikut andil dalam menentukan keputusan anak untuk hidup di jalanan. ${ }^{8}$ Bagi anak jalanan kehidupan di jalanan memberikan daya tarik sendiri, dimana mereka mendapatkan kebebasan, kesetiaan, dan dalam taraf tertentu juga memberikan perlindungan kepada anak-anak yang minggat dari rumah akibat diperlakukan salah. Sehingga semakin lama anak hidup di jalan, maka semakin sulit mereka meninggalkan dunia dan kehidupan jalanan tersebut. ${ }^{9}$

Secara garis besar anak jalanan dibedakan dalam ketiga kelompok, sebagai berikut: ${ }^{10}$

1. Children on the street, yakni anak-anak yang mempunyai kegiatan ekonomi sebagai pekerja anak di jalan, namun masih mempunyai hubungan yang kuat dengan orang tua mereka. Sebagaian penghasilan mereka di jalan diberikan kepada orang tuanya. Fungsi anak jalanan pada kategori ini adalah untuk membantu memperkuat penyangga ekonomi keluarganya karena beban atau tekanan kemiskinan yang semestinya ditanggung tidak dapat diselesaikan sendiri oleh kedua orang tuanya.

2. Children of the street, yakni anak-anak yang berpartisipasi penuh di jalanan, baik secara sosial maupun ekonomi. Beberapa di antara mereka masih mempunyai hubungan dengan orang tuannya, tetapi frekuensi pertemuan mereka tidak menentu. Banyak di antara mereka adalah anak-anak yang karena suatu sebab biasanya kekerasan lari atau pergi dari rumah. Berbagai penelitian menunjukkan bahwa anakanak pada ketegori ini sangat rawan terhadap perlakuan salah, baik secara sosial-emosional, fisik maupun seksual.

\footnotetext{
${ }^{8}$ Suyanto, Masalah Sosial Anak...hlm.210-211.

${ }^{9}$ Ibid., hlm. 212.

${ }^{10}$ Suyanto, Masalah Sosial Anak, 200-201.
} 
3. Children from families of the street, yakni anak-anak yang berasal dari keluarga yang hidup di jalanan. Walaupun anakanak ini mempunyai hubungan kekeluargaan cukup kuat, tetapi hidup mereka terombang-ambing dari satu tempat ke tempat yang lain dengan segala resikonya. Kategori ini kehidupan mereka di jalanan sudah sejak anak masih bayi bahkan masih dalam kandungan. Di Indonesia sendiri, pada kategori ini sering dijumpai di berbagai kolong jembatan, rumah-rumah liar sepanjang rel kereta api, dan sebagainya.

Perlindungan anak jalanan merupakan fokus pembangunan kesejahteraan sosial yang mencakup perlindungan sosial, sehingga model pertolongan kepada anak jalanan bukan hanya terfokus pada menghapus keberadaan anak turun ke jalan, namun juga mempertimbangkan aspek peningkatan kualitas hidup mereka serta memperhatikan hakhak dasar anak sesuai dengan aspirasi terbaik mereka, setidaknya dapat melindungi mereka dari kondisi yang eksploitatif dan diskriminasi. Maka dari itu melihat permasalahan anak jalanan yang notabennya kelompok marjinal menjadi keharusan yang harus ditangani baik oleh pemerintah maupun masyarakat agar perkembangan jumlah anak jalanan tidak terus meningkat sehingga anak-anak tersebut mendapatkan perlindungan sosial. salah satu upaya yang dilakukan pemerintah Kota Yogyakarta yaitu menerbitkan Perda No. 6 tahun 2016 tentang perlindungan anak yang hidup di jalan. Dalam kebijakan memiliki tujuan untuk mengentaskan anak dari kehidupan di jalan, menjamin pemenuhan hak-hak anak agar dapat hidup, tumbuh, berkembang, dan berpartisipasi secara optimal sesuai dengan harkat dan martabat kemanusian, serta memebrikan perlindungan dari diskriminasi, eksploitasi 
8 Khoirul Ummatin

dan kekerasan, demi terwujudnya anak yang berkualitas, berakhlak mulia, dan sejahtera. ${ }^{11}$

Dalam menerapkan kebijakan ini pemerintah Kota Yogyakarta berusaha mengupayakan cara penanganan anak jalanan dengan berbagai langkah yang tepat agar masalah anak jalanan dapat dikurangi atau bahkan dapat diatasi. Dalam prosedur penanganan anak jalanan Dinas Sosial Kota Yogyakarta tertera yang berisi target sasaran yang dibagi menjadi target langsung seperti anak yang turun ke jalan baik ikut orang tua maupun personal, anak yang dikaryakan orang lain, anak yang mengamen di jalanan, anak yang jualan koran di jalan, dan anak yang menyemir sepatu dijalan. Tidak hanya sasaran langsung yang ditujukan kepada anak jalan, namun pihak Dinas Sosial juga memiliki sasaran yang tidak langsung, seperti keluarga, masyarakat, lembaga sosial, dan lembaga pendidikan. ${ }^{12}$

Adapun dalam perda tersebut menjelaskan bahwa upaya penanganan anak jalanan meliputi dari upaya pencegahan, upaya penjangkauan, upaya pemenuhan hak dan upaya reintegrasi sosial. ${ }^{13}$

1. Upaya Pencegahan

Upaya pencegahan meliputi kampanye, edukasi, dan informasi, mengembangkan program dukunagn keluarga, mengembangkan program penguatan bagi anak yang rentan atau beresiko hidup di jalan, dan penguatan LKSA (Lembaga Kesejahteraan Sosial Anak) dan lembaga-lembaga berbasis

${ }^{11}$ Peraturan Daerah Provinsi Daerah Istimewa Yogyakarta Nomor 6 Tahun 2011 tentang Perlindungan Anak yang Hidup di Jalan Pasal 3, hlm. 4.

12 Prosedur Penanganan Anak Jalanan di Kota Yogyakarta yang dibuat oleh Dinas Sosial, Tenaga Kerja, dan Transmigrasi.

${ }^{13}$ Peraturan Daerah Provinsi Daerah Istimewa Yogyakarta Nomor 6 Tahun 2011 tentang Perlindungan Anak yang Hidup di Jalan Pasal 6, hlm. 5. 
masyarakat lain agar mampu berperan mencegah anak hidup di jalan. ${ }^{14}$

Dalam melakukan sosialisasi kepada masyarakat, salah satu contohnya yang dilakukan oleh pihak Dinas Sosial adalah memasang papan himbauan larangan dan denda untuk tidak memberikan memberikan uang di jalan yang telah tersebar di beberapa titik Kota Yogyakarta. Pengembangan program dukungan keluarga dilaksanakan melalui kegiatan-kegiatan, seperti penguatan dan pemfungsian lembaga-lembaga layanan konseling keluarga, program penguatan/pemberdayaan ekonomi keluarga, dan peningkatan ketrampilan pengasuhan bagi orang tua atau wali. Pengembangan program penguatan bagi anak yang rentan/berisiko hidup di jalan dilaksanakan melalui kegiatan-kegiatan, seperti penyelenggaraan sosialisasi pemberian edukasi dan informasi mengenai bahaya dan risiko hidup di jalan, dan penyelenggaraan kegiatan-kegiatan peningkatan keterampilan hidup (lifeskill) bagi anak, termasuk keterampilan vokasional, personal dan sosial sesuai dengan usia, minat dan kebutuhan anak. Kemudian penguatan LKSA dan lembaga-lembaga berbasis masyarakat lain dilaksanakan melalui: peningkatan kemampuan identifikasi dan penjangkauan kelompok keluarga/anak rentan atau berisiko hidup di jalan, dan peningkatan kemampuan penanganan awal terhadap situasi kelompok keluarga/anak rentan atau berisiko hidup di jalan. ${ }^{15}$

2. Upaya Pengjangkauan

Dalam upaya penjangkauan dalam penanganan anak jalanan tersebut pihak Pemerintah Daerah Istimewa Yogyakarta membuat tim perlindungan anak yang tercantum pada perda guna melaksanakan upaya pengjangkuan yang meliputi dinas yang bertugas dan bertanggung jawabnya di bidang sosial, dinas

${ }^{14}$ Peraturan Daerah Provinsi Daerah Istimewa Yogyakarta Nomor 6 Tahun 2011 tentang Perlindungan Anak yang Hidup di Jalan Pasal 7, hlm. 6.

${ }^{15}$ Ibid., Pasal 9-11, hlm. 6-7. 
$10 \mid$ Khoirul Ummatin

yang bertugas dan bertanggung jawabnya di bidang kesehatan, Kepolisian, Satuan Polisi Pamong Praja, LKSA (Lembaga Kesejahteraan Sosial Anak), Pekerja Sosial, dan Tenaga Kesejahteraan Sosial Anak. ${ }^{16}$

Dalam pelaksanaan pengjangkauan anak jalanan yang dilakukan oleh Dinas Sosial juga dibantu oleh beberapa tim yang tersebar di beberapa titik Kota Yogyakarta, dengan dibagi menjadi 3 wilayah kerja: ${ }^{17}$

a. Tim I Wilayah Utara ( Kecamatan Jetis, Lecamatan Gedongtengen, Kecamatan Tegalrejo, Kecamatan Gondokusuman, dan Kecamatan Danurejan) dengan 22 orang dengan melaksanakan kegiataan sapaan dan penjangkauan, pembinaan dan pendampingan.

b. Tim II Wilayah Tengah ( Kecamatan Gondomanan, Kecamatan Kraton, Kecamatan Ngampilan, Kecamatan Wirobrajan, Kecamatan Pakualaman) dengan 20 orang dengan melaksanakan kegiataan sapaan dan penjangkauan, pembinaan dan pendampingan.

c. Tim III Wilayah Selatan (Kecamatan Mergangsan, Kecamatan Mantrijeron, Kecamatan Umbulharjo, Kecamatan Kotagede) dengan 23 orang dengan melaksanakan kegiataan sapaan dan penjangkauan, pembinaan dan pendampingan.

Kemudian terdapat 5 orang lagi yang berada dalam sekretariat.

Adapun tahapan penanganan anak ajalanan yang dilakuakn setiap tim yang berupa sapaan dan penjangkauan, pembinaan dan pendampingan: ${ }^{18}$

a. Sapaan dan Penjangkauan 
1) Melakukan pengamatan di titik-titik lokasi yang sering digunakan untuk aktivitas jalanan.

2) Kunjungan dan membangun komunikasi terhadap anak atau pelaku aktivitas jalanan secara rutin.

3) Melakukan "teror" psikologis secara halus terhadap pelaku aktivitas jalanan.

4) Melakukan monitoring dalam rangka "sterilisasi" lokasi yang masih bersih dari aktivitas jalanan.

5) Target:

6) Setiap titik aktivitas jalanan tersentuh dan terjangkau dalam kegiataan sapaan dan penjangkauan melalui kunjungan rutin minimal seminggu sekali.

7) Dalam tiap kunjungan terdokumentasikan dalam bentuk laporan untuk melihat progress intensitas perubahan aktivitas jalanan pada titik-titik tersebut.

8) Tersampaikannya norma hidup layak sehingga menumbuhkan pemikiran bagi anak untuk mengurangi aktivitas di jalanan.

9) Tidak ada "pendatang baru" pada masing-masing titik melalui langkah antisipasi.

b. Pembinaan

1) Melaksanakan kegiatan supervisi bagi anak pelaku aktivitas jalanan dan keluarganya yang masih rentan kembali ke jalan.

2) Melakukan motivasi dan pengkondisian agar anak pelaku aktivitas jalanan tida beraktivitas di jalanan.

3) Melakukan kegiatan supervisi keluarga agar anak pelaku aktivitas jalanan bisa mendapatkan hak-haknya secara optimal.

4) Melaksanakan langkah-langkah asesing penanganan lanjutan bagi anak ( pendidikan formal atau informal, kesehatan, tumbuh kembang anak) dan keluarganya (akses pemberdayaan ekonomi, peran sosial dan 
program-program lain yang terkait dengan penanganan keluarga anak jalanan).

5) Melaksanakan kegiataan penyadaran masyarakat terkait aktivitas jalanan dan bentuk penarikan sumbangan yang tidak sah lainnya melalui sosialisasi di tingkat basis.

Target:

1) Tiap keluarga anak jalanan atau pelaku aktivitas jalanan didampingi oleh 1 orang anggota tim pembinaan.

2) Pendamping harus mampu mengidentifikasi kebutuhan dasar obyek dampingan dan melakukan aksesing pada program atau pihak lain yang bisa memenuhi kebutuhan tindak lanjut tersebut.

3) Pada obyek anak jalanan orientasi utama dari tim adalah mengembalikan mereka ke kegiatan pendidikan, sehingga pendamping wajib melakukan aksesing kepada lembaga pendidikan baik formal maupun non formal

4) Masing-masing anggota tim pembinaan melakukan sosialisasi di tingkat basis (semisal RW) terkait dengan masalah NAPZA seminggu sekali.

5) Dalam tiap kunjungan terdokumentasikan dalam bentuk laporan untuk melihat progress perubahan perilaku ekonomi dan sosial dari keluarga tersebut.

c. Pendampingan

1) Malaksanakan kegiatan supervisi bagi anak selaku aktivitas jalanan dan keluarganya yang sudah tidak beraktivitas di jalanan

2) Melakukan motivasi dan pengkondisian agar eks anak atau pelaku aktivitas jalanan konsisten dalam 
memenuhi aktivitas kembali ke pendidikan atau berusaha yang memenuhi kaidah sosial.

3) Melakukan komunikasi terhadap stakeholder di mana eks anak atau pelaku aktivitas jalanan atau keluarganya mendapatkan pelayanan lanjutan.

Target:

1) Setiap obyek keluarga yang tidak lagi beraktivitas di jalanan atau pelaku aktivitas jalanan didampingi 1 orang anggota tim.

2) Pendamping mampu mengidentifikasi kebutuhan dasar obyek pendampingan dan aksesing pada program atau pihak lain untuk tindaklanjutnya.

3) Pada obyek anak jalanan yang sudah masuk pelayanan pendidikan formal atau non formal, pendamping motivatif untuk menjaga komitmen.

4) Pada obyek anak jalanan atau pelaku aktivitas jalanan yang sudah masuk pada aktivitas kegiataan ekonomi, tim melakukan dampingan usaha motivasi agar sasaran komitmen dengan kegiataan tersebut dan tidak kembali ke kegiataan jalanan.

5) Dalam tiap kunjungan terdokumentasi dalam laporan untuk melihat progress perubahan perilaku ekonomi dan sosial dari keluarga tersebut.

3. Upaya Pemenuhan Hak

Upaya pemenuhan hak meliputi antara lain:

a. Hak identitas;

b. Hak atas pengasuhan;

c. Hak atas kebutuhan dasar;

d. Hak kesehatan;

e. Hak pendidikan; dan

f. Hak untuk mendapatkan bantuan dan perlindungan hukum.

4. Upaya Reintegrasi Sosial 
$14 \mid$ Khoirul Ummatin

Reintegrasi sosial merupakan proses pengembalian anak kepada keluarga, keluarga pengganti dan/atau masyarakat sehingga anak dapat menjalankan fungsi-fungsi sosialnya dengan baik sebagaimana anak pada umumnya. Pada upaya ini peran Pemerintah daerah, pemerintah kabupaten/Kota dan/atau LKSA sangatlah penting dalam melaksanakan upaya reintegrasi sosial bagi anak yang hidup di jalan. Dalam upaya reintegrasi sosial anak yang hidup di jalan harus didasarkan hasil penelusuran asal usul dan kondisi keluarga atau keluarga pengganti. Dan juga pihak pemerintah harus berkoordinasi dengan pemerintah daerah tempat anak tersebut berasal.

Dalam penanganan anak jalanan saat ini setelah adanya peraturan daerah berbeda dengan penanganan sebelumnya yang berubah dari yang bersifat represif atau penarikan paksa menjadi pendekatan yang manusiawi (persuasif) serta menempatkan anak di dalam posisi yang bermartabat. Dalam upaya penjangkauan anak yang hidup di jalan tersebut, pekerja sosial memiliki peran yang sangat penting, sedangkan aparat di bidang ketertiban umum atau satpol PP berada di posisi belakang sebagai pengaman. Selanjutnya, penjangkauan dilakukan lebih personal dengan pendekatan pribadi tiap anak, sehingga dapat diketahui secara lebih jelas permasalahan yang dihadapi setiap anak. ${ }^{19}$

Berdasarkan data jumlah anak jalanan di Daerah Istimewa Yogyakarta dalam kurun waktu 5 tahun terakhir yakni 2015-2019 mengalami kenaikan dan penurunan jumlah anak jalanan, seperti pada tahun 2015 memiliki berjumlah 497.000 orang, kemudian pada tahun 2016 terlihat mengalami penurunan menjadi 212.000, satu kemudian yakni tahun 2017 mengalami kenaikan menjadi 220,000, selanjutnya tahun 2018

19 http://dinsos.jogjaprov.go.id/penjangkauan-a4nak-yang-hidup-dijalan/. diakses pada tanggal 15 Juni 2019 pada pukul 09.35. 
mengalami penurunan menjadi 219,000, namun pada tahun 2019 terlihat adanya kenaikan yang cukup drastis yakni 327,000. ${ }^{20}$

Ada beberapa faktor yang menjadi penghambat kebijakan penanganan anak jalanan di Kota Yogyakarta, yakni keterbatasan anggaran dana di dalam kebijakan penanganan anak jalanan menyebabkan pembinaan anak jalanan kurang efektif, belum adanya peranan perusahaan swasta dalam kebijakan penanganan anak jalanan, lingkungan sosial keluarga anak jalanan di Kota Yogyakarta menyebabkan ana turun ke jalan, lingkungan ekonomi Kota Yogyakarta menjadi daya tarik anak jalanan dari berbagai daerah. ${ }^{21}$

Selain itu, apabila diamati faktor lain yang menjadi kendala kebijakan tersebut yakni masih adanya masyarakat memiliki kencenderungan untuk memberi uang di jalanan, dimana sudah menjadi kebiasaan ketika ada orang memintaminta di jalan, membuat masyarakat iba dan mudah untuk diberikan uang. Padahal hal ini menjadikan banyak anak untuk turun ke jalan meminta uang, mereka menganggap tidak usah bersusah payah bekerja untuk mencari uang, karena dengan meminta di jalan pun mereka sudah bisa mendapatkan uang. Akan tetapi untuk mencegah hal tersebut Pemerintah Kota Yogyakarta juga mengeluarkan Perda Larangan Beri Uang kepada Anak Jalanan, Gelandangan dan Pengemis serta upaya memasang baliho atau papan imbauan di tempat-tempat strategis tentang larangan memberi uang.

\section{Tinjauan Maqasid syariah}

Setelah menjelaskan penanganan anak jalanan berdasarkan kebijakan pemerintah yang tertuang dalam perda,

20 http://bappeda.jogjaprov.go.id/dataku/data_dasar?id_skpd=5 di akses pada tanggal 15 Juni 2019 pada pukul 09.30 WIB

s1.undip.ac.id/index.php/jppmr/article/viewFile/8335/8102 di akses pada tanggal 16 Juni 2019 pada pukul 07.39 WIB. 
$16 \mid$ Khoirul Ummatin

kemudian kebijakan tersebut dilihat dari pandangan islam menurut maqasid syariah terkait tujuan dan agenda penerapan kebijakan anak jalanan di Kota Yogyakarta. Pertama-tama penjabaran terkait pengertian dari maqasid syariah. Di kalangan ulama ushul fiqh, tujuan sebuah hukum biasanya disebut dengan maqasid syariah, yang memiliki tujuan syar'i dalam menetapkan hukum. Tujuan hukum tersebut dapat dipahami malalui penelusuran terhadap ayat Al-qur'an dan sunnah Rosulullah. ${ }^{22}$ Kemudian Al-Syatibi menjabarkan pengertian mengenai maqasid syariah sebagai berikut maqasid syariah ditinjau dari segi bahasa terdiri dari dua kata, yakni maqasid dan syari'ah. Maqasid adalah bentuk jama' dari maqasid yang berarti kesengajaan atau tujuan. Sedangkan syari'ah memiliki arti jalan menuju sumber air atau dapat dikatakan sebagai jalan ke arah sumber pokok kehidupan. Variasi definisi dari maqasid syariah mengindikasikan adanya kaitan erat dengan hikmah, 'illat, tujuan atau niat, dan kemaslahatan. ${ }^{23}$

Definisi maqasid syariah menurut Al-Ghazali maslahah adalah sebuah istilah yang pada intinya merupakan keadaan yang mendatangkan manfaat dan menolak bahaya atau kerugian. Yang kami maksudkan dengan maqashid al-syari'ah sebenarnya bukan ini, karena mendatangkan menfaat dan menolak bahaya atau kerugian adalah tujuan dari makhluk. Kebaikan makhluk adalah ketika menggapai tujuan-tujuannya. Yang kami maksud dengan maqashid al-syari'ah di sini adalah menjaga tujuan syara' ${ }^{24}$

${ }^{22}$ Abd. Rahman Dahlan, Ushul Figh, ( Jakarta: Amzah, 2011), 304.

${ }^{23}$ Asafri Jaya Bakri, Konsep Maqasid Al-Syari'ah Menurut Al-Syatibi, (Jakarta: PT. RajaGrafindo, 1996), 61.

${ }^{24}$ Ahmad Imam Mawardi, Figh Minoritas; Figh Al-Aqalliyat dan Evolusi Maqasid Al-Syari'ah dari Konsep ke Pendekatan, ( Yogyakarta: LKIS Group, 2010), 180-181. 
Adapun tujuan syara' untuk makhluk ada lima, sebagai berikut: ${ }^{25}$

1. Melestarikan terhadap agama.

2. Melestarikan terhadap jiwa.

3. Melestarikan terhadap akal.

4. Melestarikan terhadap keluarga.

5. Melestarikan terhadap harta benda.

Kemudian menurut Al-Syatibi dalam mewujudkan dan memelihara lima unsur pokok tersebut, adanya pembagian menjadi tiga tingkatan maqasid atau tujuan syariah, yaitu: Maqasid al-Daruriyat (primer) yakni tingkat kebutuhan yang harus dipenuhi, Maqasid al-Hijiyat (sekunder) yakni kebutuhan yang bilamana tidak diwujudkan tidak sampai mengancam keselamatan akan tetapi akan mengalami kesulitan, dan Maqasid al-Tahsiniyat (tersier) yakni kebutuhan pelengkap bilamana tidak terpenuhi tidak mempengaruhi dan menimbulkan kesulitan. ${ }^{26}$

Dalam dalil-dalil syara' mewajibkan dijalankannya jaminan hak manusia dan menjadikan pemerintah memiliki tanggung jawab terhadap rakyatnya, dan juga mewajibkan pemerintah untuk memperhatikan urusan semua orang yang berada di bawah kekuasaanya, melindungi, menjaga hak, dan berbuat adil kepada mereka. ${ }^{27}$

Dalam sudut pandangan agama Islam, anak merupakan makhluk yang dhaif dan mulia, yang keberadaannya adalah atas kewenangan dan kehendak Allah SWT dengan melalui beberapa proses penciptaanya yang dimensinya sesuai dengan kehendak Allah Swt. Kedudukan anak dalam Agama Islam ditegaskan dalam Al-qur'an Surah Al-Isra' ayat 70 yakni:

${ }^{25}$ Jaser Audah, Al-Maqasid untuk Pemula, ( Yogyakarta: Suka Press, 2013), 8 .

${ }^{26}$ Bakri, Konsep Maqasid Al-Syari'ah, 72.

${ }^{27}$ Ahmad Al-Mursi Husain Jauhar, Maqashid Syariah, (Jakarta: Amzah, 2009), 15. 
18 Khoirul Ummatin

"Dan sesungguhnya telah Kami muliakan Anak-anak Adam. Kami angkut mereka di daratan dan di lautan. Kami beri rezki dari yang baik-baik dan Kami lebihkan mereka dengan kelebihan yang sempurna atas kebanyakan makhluk yang telah Kami ciptakan".

Penjelasan Surah Al-qur'an tersebut diikuti dengan Hadist Nabi Muhammad Saw yang artinya "Semua anak dilahirkan atas kesucian, sehingga ia jelas bicaranya". Maka dapat dilihat bahwa dalam ajaran Islam pun keberadaan anak menjadi yang penting untuk dilindungi. Karena memiliki peranan penting sebagai generasi penerus terdahulu yang seharusnya menjadi harapan bagi mayarakat di masa yang akan datang. Sudah seharusnya anak mendapatkan hak untuk tumbuh berkembang menjadi sosok yang baik, baik secara rohani dan jasmani. ${ }^{28}$

Dapat dilihat perlindungan anak dari sisi islam merupakan bagian penting, terlebih anak yang termarjinalkan seperti anak jalanan yang kurang mendapatkan akses. Untuk itu penanganan yang tertuang dalam Perda No. 6 tahun 2011 tentang perlindungan anak yang hidup di jalan, apabila dikaji menurut maqasid syariah menempati pada tingkatan maqasid alDaruriyat, karena seorang anak memiliki hak yang harus dijamin, dilindungi, dan dipenuhi bukan hanya oleh pihak pemerintah saja akan tetapi orang tua, keluarga, masyarakat. Dalam serangkaian upaya yang dilakukan oleh pemerintah dalam menangani anak jalanan, apabila upaya terakhir telah dijalankan dirasa memenuhi kebutuhan anak jalanan, maka anak tersebut akan dikembalikan lagi kepada keluarganya untuk menjalankan kehidupan sebagaimana semestinya.

${ }^{28}$ Tedy Sudrajat, "Perlindungan Hukum Terhadap Hak Anak Sebagai Hak Asasi Manusia Dalam Perspektif Sistem Hukum Keluarga di Indonesia", Jurnal Ilmu Hukum Universitas Syiah Kuala No. 54 Th. XIII (Agustus,2011), 126.

www.jurnal.unsyiah.ac.id/kanun/article/download/6245/5150 (diakses 10 Juni 2019). 
Selain itu dalam Perda apabila ditinjau dari sisi maqasid syari'ah demi mencapai sebuah kemaslahahan dapat mencakup sebagai berikut: upaya pencegahan, penjangkauan, reintegrasi sosial termasuk melindungi kebutuhan melestarikan terhadap keluarga (hifz al nasl), dengan melakukan sosialisasi, edukasi dan informasi kepada orang sekitar anak seperti keluarga untuk pencegahan anak turun ke jalan, serta upaya pemerintah untuk pengembalian anak kepada keluarga sehingga anak bisa menjalani hak-hak mereka, sebagaimana semestinya anak merupakan sebuah amanah yang menjadi tanggung jawab sebuah keluarga dan juga orang tua memiliki tanggung jawab yang besar untuk menjaga serta mendidik anaknya. Orang tua lah yang pertama membentuk karakter anak dan melindungi anak sehingga kebutuhan anak terpenuhi dan mendapatkan kesejahteraan. Dan perda ini masuk ke dalam tingkatan khusus, karena untuk melindungi keutuhan keluarga yang sebagaimana semestinya anak harus di bawah perlindungan orang tua dan keluarga. Upaya pemenuhan hak anak termasuk aspek Hifz alNafs (perlindungan jiwa) yang mencakup keselamatan dan kesehatan anak jalanan yang rentan saat berada di jalan, seperti rentan sakit karena polusi dan cuaca yang tak menentu, dan adanya kemungkinan mengalami kecelakaan saat berada di jalan, serta anak jalanan berhak atas kebutuhan dasar mereka yakni sandang, papan, dan tempat tinggal, tidak hanya tinggal di jalanan dikarenakan mencari nafkah. kemudian aspek Hifz alaql (pelestarian terhadap akal) dimana adanya pemenuhan hak pendidikan anak yang seharusnya, setiap anak berhak mendapatkan kesempatan yang sama untuk mendapatkan pendidikan yang layak, malah berbanding sebaliknya pendidikan anak jalanan terhambat karena turun ke jalan untuk mencari nafkah.

\section{Penutup}


$20 \mid$ Khoirul Ummatin

Pandangan maqasid syariah yang memiliki tujuan menetapkan hukum untuk kemaslahatan manusia baik di dunia maupun di akhirat tertuang dalam penetapan kebijakan masalah penanganan anak jalanan dimana Pemerintah mengupayakan solusi terbaik untuk mengentaskan anak jalanan dengan cara memenuhi hak-hak anak jalanan sebagaimana semestinya dengan cara kemanusiawan (persuasif) yang sebagaimana diharapkan dapat mengurangi atau bahkan mengatasi jumlah anak jalanan di Kota Yogyakarta. Dengan beberapa upaya seperti, upaya pencegahan, upaya penjangkauan, upaya pemenuhan hak dan upaya reintegrasi sosial. hal tersebut termasuk ke dalam tingkatan maqasid alDaruriyat (kemaslahatan primer) karena anak jalanan memiliki hak yang sama seperti anak yang lain untuk dilindungi oleh keluarga, pemerintah dan masyarakat sehingga mereka berhak memperoleh masa depan yang lebih baik.

\section{Daftar Pustaka}

Audah, Jaser. Al-Maqasid untuk Pemula. Yogyakarta: Suka Press, 2013.

Bakri, Asafri Jaya. Konsep Maqasid Al-Syari'ah Menurut Al-Syatibi. Jakarta: PT. RajaGrafindo, 1996.

Dahlan, Abd. Rahman. Ushul Figh. Jakarta: Amzah, 2011.

Jauhar, Ahmad Al-Mursi Husain. Maqashid Syariah. Jakarta: Amzah, 2009.

Kalida, Muhsin dan Bambang Sukamto. Jejak Kaki Kecil di Jalanan. Yogyakarta: Cakruk Publishing, 2012.

Mawardi, Ahmad Imam. Figh Minoritas; Figh Al-Aqalliyat dan Evolusi Maqasid Al-Syari'ah dari Konsep ke Pendekatan. Yogyakarta: LKIS Group, 2010.

Setyowati Soemitro, Irma. Aspek Hukum Perlindungan Anak . Jakarta: Bumi Aksara, 1990.

Suyanto, Bagong. Masalah Sosial Anak. Jakarta: Kencana, 2010. 
Suharto, Edi. Pekerjaan Sosial di Indonesia Sejarah Dinamika dan Perkembangan. Yogyakarta: Samudra Biru, 2011

\section{Dokumen}

Peraturan Daerah Provinsi Daerah Istimewa Yogyakarta Nomor 6 Tahun 2011 tentang

Perlindungan Anak yang Hidup di Jalan.

Prosedur Penanganan Anak Jalanan di Kota Yogyakarta yang dibuat oleh Dinas Sosial, Tenaga Kerja, dan Transmigrasi.

Undang-Undang Republik Indonesia Nomor 23 Tahun 2002 tentang Perlindungan Anak.

Website

Edy Sudrajat, "Perlindungan Hukum Terhadap Hak Anak Sebagai Hak Asasi Manusia Dalam Perspektif Sistem Hukum Keluarga di Indonesia", Jurnal Ilmu Hukum Universitas Syiah Kuala No. 54 Th. XIII (Agustus,2011), 126.

www.jurnal.unsyiah.ac.id/kanun/article/download/6245/5150

(diakses 10 Juni 2019).

http://dinsos.jogjaprov.go.id/penjangkauan-a4nak-yang-hidupdi-jalan/. diakses pada tanggal 15 Juni 2019 pada pukul 09.35 WIB.

http://bappeda.jogjaprov.go.id/dataku/data_dasar?id_skpd=5 di akses pada tanggal 15 Juni 2019 pada pukul 09.30 WIB. http://ejournal-

s1.undip.ac.id/index.php/jppmr/article/viewFile/8335/81 02 di akses pada tanggal 16 Juni 2019 pada pukul 07.39 WIB. 